\title{
Biochemical Alterations Induced by Amylin in Wistar Rats
}

\author{
${ }^{1,2}$ Mohamed Mohamed Soliman and ${ }^{3,4}$ Zein Shaban Ibrahim \\ ${ }^{1}$ Department of Medical Laboratories, Faculty of Applied Medical Sciences, Turabah, Taif University, Saudi Arabia \\ ${ }^{2}$ Departments of Biochemistry, Faculty of Veterinary Medicine, Benha University, Moshtohour, P.O. 13736, Egypt \\ ${ }^{3}$ Department of Physiology and Internal Medicine, Faculty of Medicine, Taif University, Saudi Arabia \\ ${ }^{4}$ Departments of Physiology, Faculty of Veterinary Medicine, Kafr El-Sheikh University, Egypt
}

Received 2013-05-27, Revised 2013-06-03; Accepted 2013-06-07

\begin{abstract}
Amylin is a peptide hormone synthesized in $\beta$ cells of pancreas together with insulin in response to glucose and nutrients. Amylin controls food intake and body weight but the exact mechanism is still unknown. This study aimed to examine the effects of amylin injection on hormones, metabolites and cytokines expression in rats. Wistar rats were injected amylin Intraperitoneally (IP) $\left(10 \mu \mathrm{g} \mathrm{kg}^{-1}\right.$ twice daily) for 7 days. Plasma and liver samples were collected for blood measurements and RT-PCR analysis. Amylin treatments induced significant decrease in body weight and food intake in time dependent manner. Moreover, amylin significantly increased insulin, leptin and lipase secretion. A decrease in plasma triglycerides, cholesterol and LPL and increase in HDL levels was recorded. There are upregulation in the expression of IL-1 $\beta$ and TNF- $\alpha$ in amylin treated rats. The results collectively indicate that amylin has anti-obesity like effects through regulation of proteins and obesity related gene expression.
\end{abstract}

Keywords: Amylin, Effects, Obesity, Wistar Rats

\section{INTRODUCTION}

Amylin is a pancreatic 37 -amino acid peptide cosecreted together with insulin from islet beta cells. Amylin protein and mRNA are present in the lung, stomach, duodenum, jejunum, ileum, colon and rectum and throughout the CNS (Cooper, 1994). Mature bioactive amylin undergoes post-translational modifications (intra-molecular disulfide bond and $\mathrm{COOH}$-terminal amidation) which is essential for its bioactivity (Christopoulos et al., 2003). Circulating amylin exists in both non-glycosylated and glycosylated forms in normal and diabetic human subjects (Christopoulos et al., 2003). Amylin secretion is stimulated by glucagon, glucagone like peptide-1and cholinergic agonists and its secretion inhibited by somatostatin and insulin (Hay et al., 2004). Amylinbinding sites have been detected in pancreatic-cells, skeletal muscle, kidney, lung and brain (Muff et al., 2001). Functional amylin receptors are generated by coexpression of the G-protein-coupled calcitonin receptor gene and Receptor Activity-Modifying Proteins (RAMPs) (Christopoulos et al., 2003). The potential for the combination of calcitonin receptor isoforms and different RAMP proteins gives rise to at least six different subtypes of amylin receptors that display unique pharmacological properties (Hay et al., 2004). RAMP-1 and -3 mRNAs are co-localized with calcitonin receptor gene mRNA in mouse pancreatic-cells (Martinez et al., 2000). Amylin modulates the secretion and/or peripheral sensitivity of insulin, thereby regulates glucose homeostasis (Butler et al., 1990).

Amylin controls various peripheral metabolic functions by controlling blood glucose levels and rate of stomach emptying (Rushing et al., 2000a; 2000b) and reduction in food intake (Butler et al., 1990; Cooper,

Corresponding Author: Mohamed Mohamed Soliman, Departments of Biochemistry, Faculty of Veterinary Medicine, Benha University, Moshtohour, P.O. 13736, Egypt Tel: 0020122-3722404; 00966501531640 
1994). The effect of amylin on food intake affect mainly the short-term control of meal size as amylin injection transiently reduces food intake (Lutz et al., 1994; 1998). Moreover, mouse with targeted deletion of amylin gene has higher weight gain than wild type (Gebre-Medhin et al., 1998) and treatment with amylin antagonists increase food intake and body weight (Rushing et al., 2001). In rodents, amylin crosses the blood-brain barrier and binds to brain receptors located in brain areas involved in the regulation of energy homeostasis such as the area postrema/nucleus of the solitary tract region and the hypothalamus (Lutz et al., 2001). Central bolus infusion of amylin 100 pM into the third ventricle significantly decreased $24 \mathrm{~h}$ food intake by over 30\% in rats (Rushing et al., 2000a; 2000b). Amylin circulates in the plasma at concentrations with a mean of $3.4 \pm 0.7 \mathrm{pM}$ in lean subjects and $4.7 \pm 0.9 \mathrm{pM}$ in obese subjects with normal glucose tolerance (Hartter et al., 1991). Furthermore, chronic peripheral or intracerebroventricular infusion of amylin into rats results in reduction in food intake and weight loss (Rushing et al., 2000a; 2000b; 2001). The acute glucoregulatory actions of exogenous amylin include inhibition of gastric emptying and glucagon secretion, with sustained amylin administration induced reduction in food intake and weight loss (Rushing et al., 2000a). Amylin-/-mice are healthy and exhibit enhanced glucose clearance and increased sensitivity to the diabetogenic effects of alloxan (Wang et al., 1999; Mulder et al., 2000). The physiological importance of the satiety effect of amylin is reflected by enhanced weight gain of amylin-/-mice, which also exhibit reduced responsivity to the anorectic actions of exogenous cholecystokinin and bombesin (Mollet et al., 2003). The concurrent infusion of amylin and leptin synergistically was shown to reduce food intake and body weight and specifically lowered fat mass, in Diet-Induced Obesity (DIO)-prone rats (Roth et al., 2008; Trevaskis et al., 2008). Moreover, amylin plus leptin mediated weight loss was reported to be not only through reduced food intake but also by enhancing systemic lipid metabolism manifested by significantly lowering plasma triglycerides and total cholesterol levels (Trevaskis et al., 2010). Liver like adipose tissue and many other tissues secrets numerous proteins that implicated in regulation of several pathways in body during health or disease named cytokines. The adipokines are implicated in glucose tolerance and insulin sensitivity (adiponectin and resistin), antiobesity function (leptin) and some cytokines such as IL- 1, TNF- $\alpha$ and IL- 6 that are involved in lipid metabolism and in inflammation and stress response such as haptoglobin (Trayhurn and Beattie, 2001). Most of already established data focused on the effect of amylin on food intake and body weight but no clear studies elucidated the effect of amylin on insulin, leptin, lipid profiles and adiposity related cytokines expression and that was the target of this study.

\section{MATERIALS AND METHODS}

\subsection{Materials}

Rat amylin was obtained from sigma Aldrich, The Wistar albino rats were bought from Egyptian Co for experimental animals import, Helwan, Egypt. Vehicles and related materials were from ADWIA pharmaceutical company, Egypt, Heparinzed vacuteiner tubes, TriZol reagents, Poly dT, chloroform, ethanol and cytokines primers were from Wako pure chemicals, Osaka, Japan.

\subsection{Animals and Experimental Procedures}

All experimental procedures were approved by the dean of Scientific Research for Faculty of Applied Medical Sciences, Taif University, Saudi Arabia. Thirty male Wistar rats, 7 weeks age (220-240 g), were divided into two groups of fifteen rats each, were housed at room temperature $\left(24 \pm 1^{\circ} \mathrm{C}\right)$ with a 12 -h light and 12-h dark cycle and get open access to food intake. Rats were handled daily for 10 days to recover the stress and injection effect. First group (saline injected rats) were injected twice daily by saline and the second (amylin treated rats) were Intraperitoneally (IP) injected amylin twice daily in a dose of $10 \mu \mathrm{g} \mathrm{kg}^{-1}$ at morning and evening for 7 days. Six hours after the last injection, rats decapitated and blood and organs collected for various measurements. Food intake and body weight were measured as indicated in figures. Plasma was extracted and kept at $-20^{\circ} \mathrm{C}$ till assays and liver samples were kept in TriZol reagent till RNA extraction and RT PCR analysis.

\subsection{Biochemical Measurements}

Plasma glucose concentrations were measured using an automatic analyzer (COBAS MIRA, F. Hoffmann-La Roche, Basel, Switzerland). Plasma insulin was measured using commercial human kits from Peninsula, San Carlos, CA, USA. Plasma leptin was assayed using rat leptin ELISA kit (LINCO Research Inc., St. Charles, MO, USA). Plasma kit for pancreatic lipase was from Mabaret El Asafraa, Alexandria, Egypt. Lipid profiles were measured spectrophotometrically based on kits supplied by Wako Pure chemicals, Osaka, Japan. 
Table 1. PCR cycle of respective genes are shown, while temperature and time of denaturation and elongation steps of each PCR cycle are $94^{\circ} \mathrm{C}, 30 \mathrm{~s}$ and $72^{\circ} \mathrm{C}, 60 \mathrm{~s}$, respectively

\begin{tabular}{|c|c|c|c|}
\hline mRNA & Forward & Reverse & Annealing \\
\hline$\beta$-actin (628 bp) & 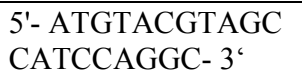 & $\begin{array}{l}\text { 5'-TCCACACAGAG } \\
\text { TACTTGCGC -3' }\end{array}$ & $\begin{array}{l}\text { Annealing at } 56.5^{\circ} \mathrm{C} \\
\text { for } 1 \text { min sec for } 25 \text { cycles }\end{array}$ \\
\hline TNF- $\alpha$ (360 bp) & $\begin{array}{l}\text { 5'- GTAGCCCACGT } \\
\text { CGTAGCAAA-3“' }\end{array}$ & $\begin{array}{l}\text { 5'- CCCTTCTCCA } \\
\text { GCTGGAAGAC-3' }\end{array}$ & $\begin{array}{l}\text { Annealing at } 56^{\circ} \mathrm{C} \\
\text { for } 1 \mathrm{~min}\end{array}$ \\
\hline IL-1 $\beta$ (218 bp) & $\begin{array}{l}\text { 5'-ATGGCAACCGT } \\
\text { ACCTGAACCCA-3' }\end{array}$ & $\begin{array}{l}\text { 5'-GCTCGAAAAT } \\
\text { GTCCCAGGAA-3' }\end{array}$ & $\begin{array}{l}\text { Annealing at } 60^{\circ} \mathrm{C} \\
\text { for } 30 \mathrm{sec}\end{array}$ \\
\hline
\end{tabular}

\subsection{RT-PCR Analysis and Gene Expression}

Livers samples were collected from all rats and flash frozen in liquid nitrogen and subsequently stored at $70^{\circ} \mathrm{C}$. Frozen liver samples (approximately $100 \mathrm{mg}$ of tissue per sample) were immediately added to $1 \mathrm{~mL}$ of TRIzol reagent (Invitrogen, Carlsbad, CA) and homogenized using a Polytron 300D homogenizer (Brinkman Instruments, Westbury, NY). One milliliter of the tissue homogenate was transferred to a microfuge tube and total RNA was extracted via chloroform extraction followed by nucleic acid precipitation with isopropanol. The pellet was washed with $75 \%$ ethanol and resuspended in molecular biology grade water. Nucleic acid concentration was determined by o.d. $260 \mathrm{~nm}$ (Smart-Spec; Bio-Rad Laboratories, Hercules, CA) and RNA integrity was evaluated using an Agilent bioanalyzer (model 2100; Agilent Technologies, Foster City, CA).

RNA $(1 \mu \mathrm{g})$ was treated at $72^{\circ} \mathrm{C}$ for $5 \mathrm{~min}$ and reverse transcribed using 100 units of Moloney murine leukemia virus reverse transcriptase (Gibco), 50 pmol of poly (dT) primer and $20 \mathrm{nmol}$ of dNTPs in a total volume of $10 \mu \mathrm{L}$ at $37^{\circ} \mathrm{C}$ for $1 \mathrm{~h}$. After heating at $94^{\circ} \mathrm{C}$ for $5 \mathrm{~min}$, PCR amplification was performed with 2.5 units Taq polymerase (Perkin-Elmer, Foster City, CA, USA), 3 $\mathrm{mM} \mathrm{MgCl} 2$ and 50 pmol of forward and reverse primers specific for respective genes in a total volume of $50 \mu \mathrm{L}$. The PCR conditions for different tested genes are shown in Table 1. After electrophoresis in 1.5\% agarose gel, the PCR products were stained with ethidium bromide and visualized under UV lamp. Intensities of PCR bands were analyzed densitometrically using NIH Image program (http://rsb.info.nih.gov/nih-image/).

\subsection{Statistical Analysis}

Results are expressed as means \pm S.E. of independent experiments. Statistical analysis was done using ANOVA and Fischer's post hoc test, with $\mathrm{p}<0.05$ being considered as statistically significant.

\section{RESULTS AND DISCUSSION}

\subsection{Effect of Amylin on Body Weight and Food Intake Changes in Wistar Rats}

This study was carried out to identify the effect of amylin on food intake and body weight. As shown in Fig. 1, amylin injection induced significant $(\mathrm{p}<0.05)$ decrease in food intake (Fig. 1A), start from day 2 $(67 \pm 10 \%)$ and continued until day 7 of experiment $(34 \pm 10 \%)$. Consistent decrease in body weight (Fig. 1B) was recorded (from $180 \pm 4 \mathrm{~g}$ at 2 days from injection to $140 \pm 6 \mathrm{~g}$ at 7 at days of treatment).

\subsection{Effect of Amylin on Plasma Levels of Insulin, Glucose, Leptin and Lipase in Wistar Rats}

Amylin injection twice daily for 7 days induced significant $(p<0.05)$ changes in various hormones and metabolites. The anti-obesity like effects of amylin was clear through its effect on insulin, leptin and lipase levels. As seen in Fig. 1C, amylin induced a significant increase in insulin $(30.2 \pm 2.17$ versus $14.25 \pm 1.75 \mu \mathrm{IU}$ $\mathrm{mL}^{-1}$ ) in amylin injected rats compared to saline injected rats respectively. The increase in insulin level leads to a concomitant decrease in glucose levels $(150 \pm 5.5$ versus $89 \pm 3.56 \mathrm{mg} \mathrm{dl}^{-1}$ ) in amylin injected rats compared to saline injected rats respectively (Fig. 1D). Moreover, there is an increase in leptin levels $\left(2.6 \pm 0.2 \mathrm{ng} \mathrm{mL}^{-1}\right.$ for amylin treated rats versus $1.03 \pm 0.11 \mathrm{ng} \mathrm{mL}^{-1}$ in control respectively) as seen in Fig. 1E. The changes in lipase levels showed an increase in lipase levels $(29.62 \pm 3.95$ $\mathrm{U} / \mathrm{L}$ versus $11.5 \pm 1.04$ in treated and control respectively). As, lipase acts as a lipolytic agent to increase fatty acids oxidation and lowers TG levels in blood as seen in amylin injected rats (Fig. 1F).

\subsection{Effect of Amylin on Lipid Profiles in Wistar Rats}

Next, we tested the effect of amylin on cholesterol, triglycerides, low and high density lipoproteins. 


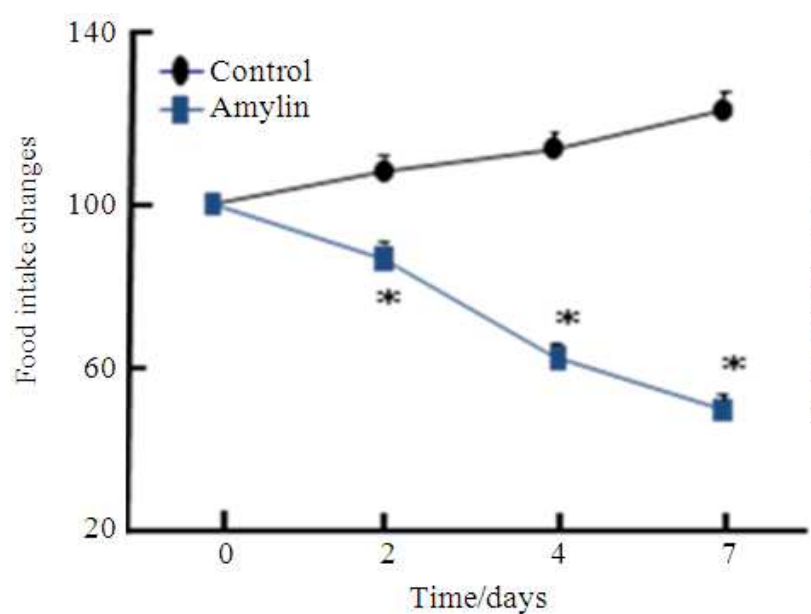

(A)

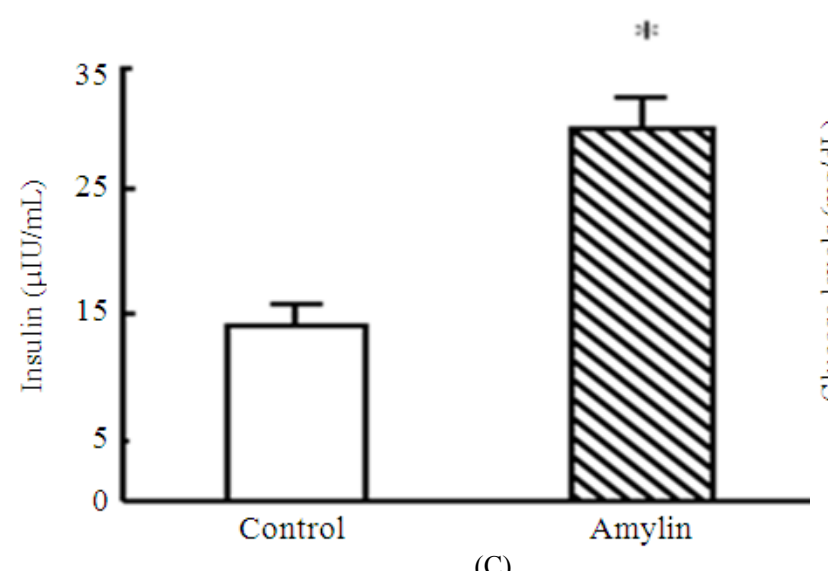

(C)

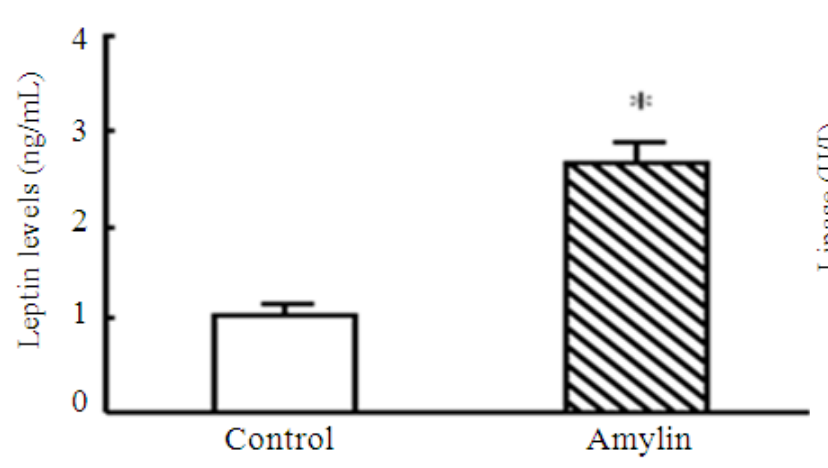

(E)

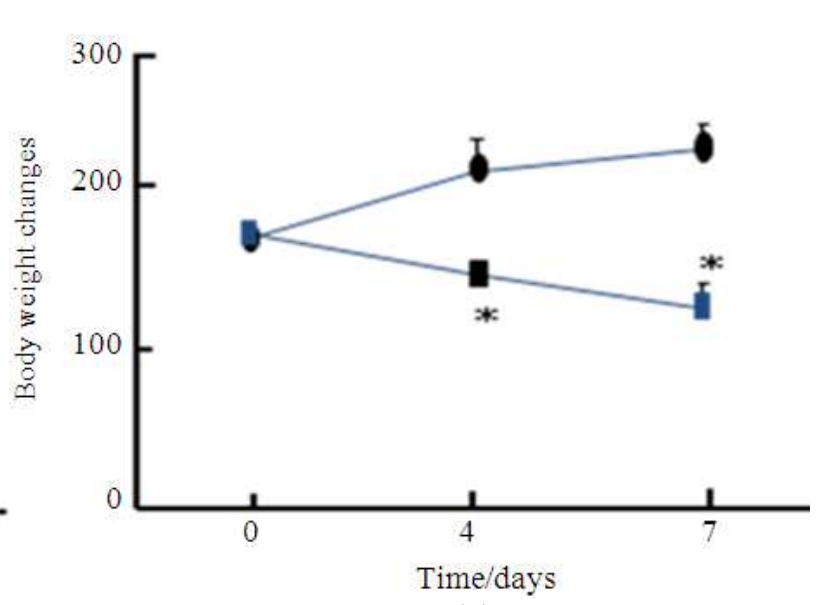

(B)

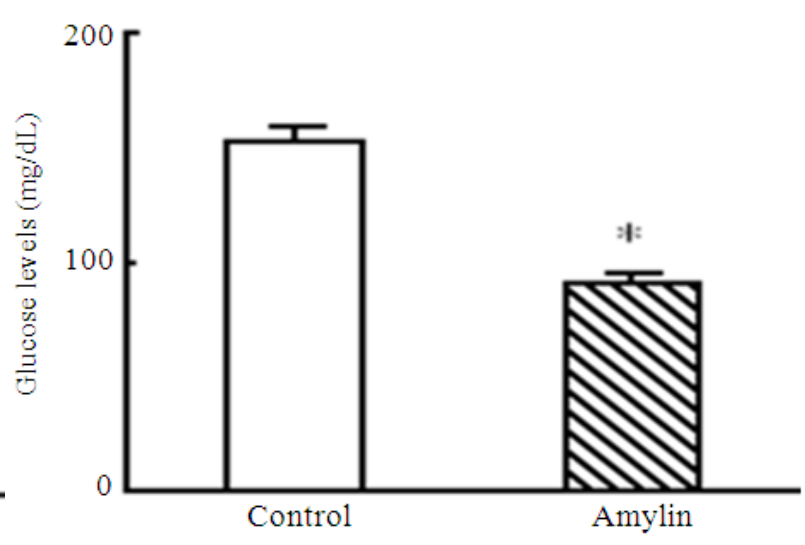

(D)

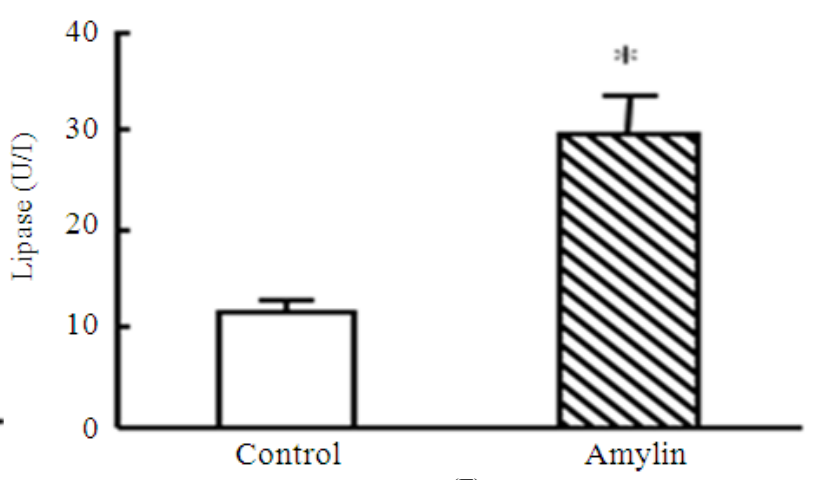

(F)

Fig. 1. Changes in food intake (A), body weight (B), insulin (C), glucose (D), leptin (E) and lipase (F) after amylin injection in Wistar rats. Rats were injected intraperitoneally (IP) in doses of $10 \mu \mathrm{g} \mathrm{kg}^{-1}$ twice daily for 7 days. Blood was collected $6 \mathrm{~h}$ after last amylin dose injection and plasma was extracted for various biochemical measurements described in materials and methods. Values are means \pm S.E. of 10 different rats. ${ }^{*} \mathrm{p}<0.05$ vs. control (saline injected rats) 
Soliman, M.M. and Z.S. Ibrahim / American Journal of Pharmacology and Toxicology 8 (2): 64-72, 2013
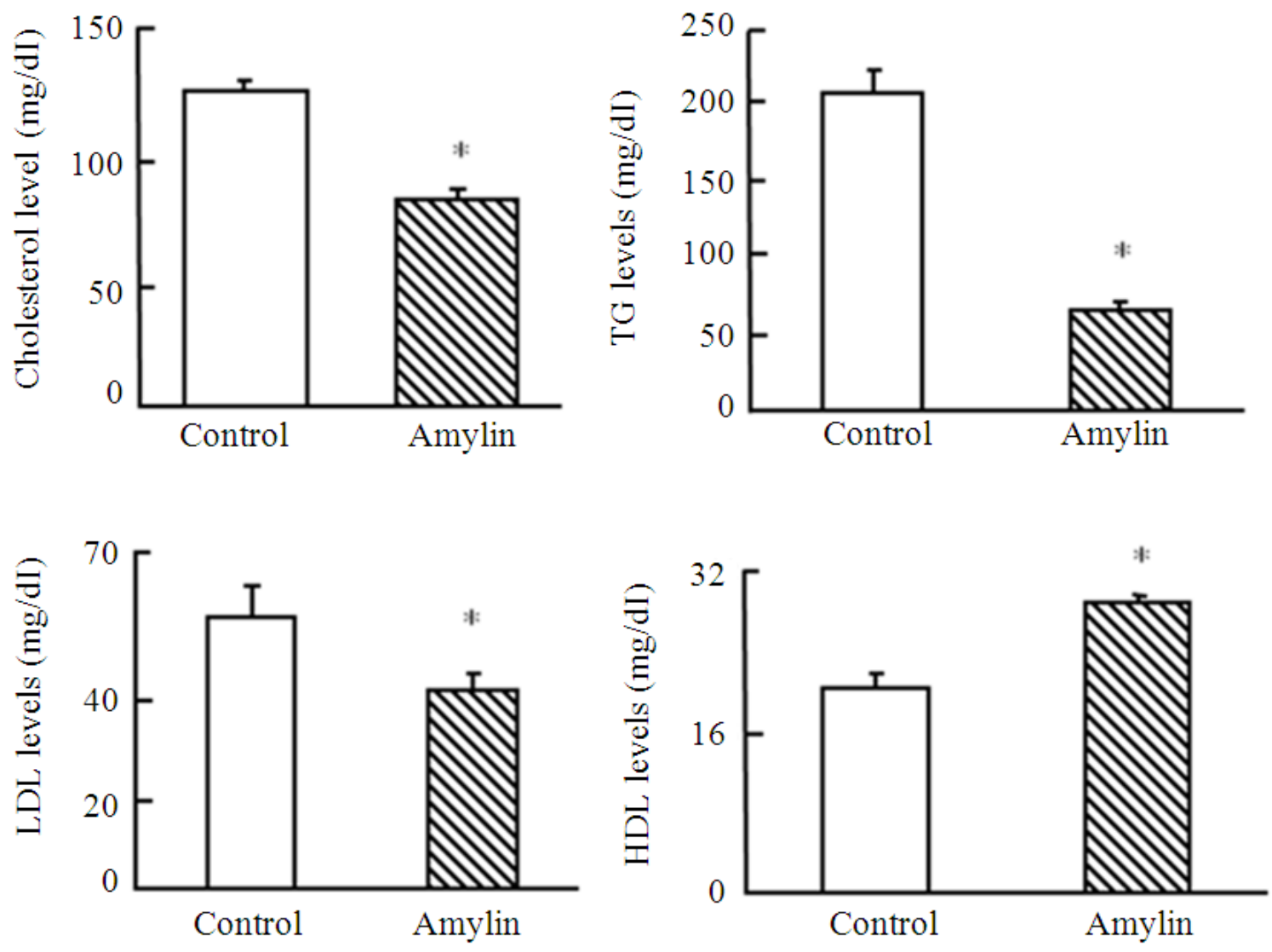

Fig. 2. Changes in plasma cholesterol, triglycerides, LDL and HDL after amylin injection in Wistar rats. Rats were injected amylin $(10 \mu \mathrm{g} / \mathrm{kg} /$ day $)$ IP twice daily for 7 days. Blood was collected $6 \mathrm{~h}$ after last dose injected and plasma was assayed for cholesterol, triglycerides, LDL and HDL as described in materials and methods. Values are means \pm S.E. of 10 different rats. ${ }^{*} \mathrm{p}<0.05$ vs. control (saline injected rats)

TNF- $\alpha$
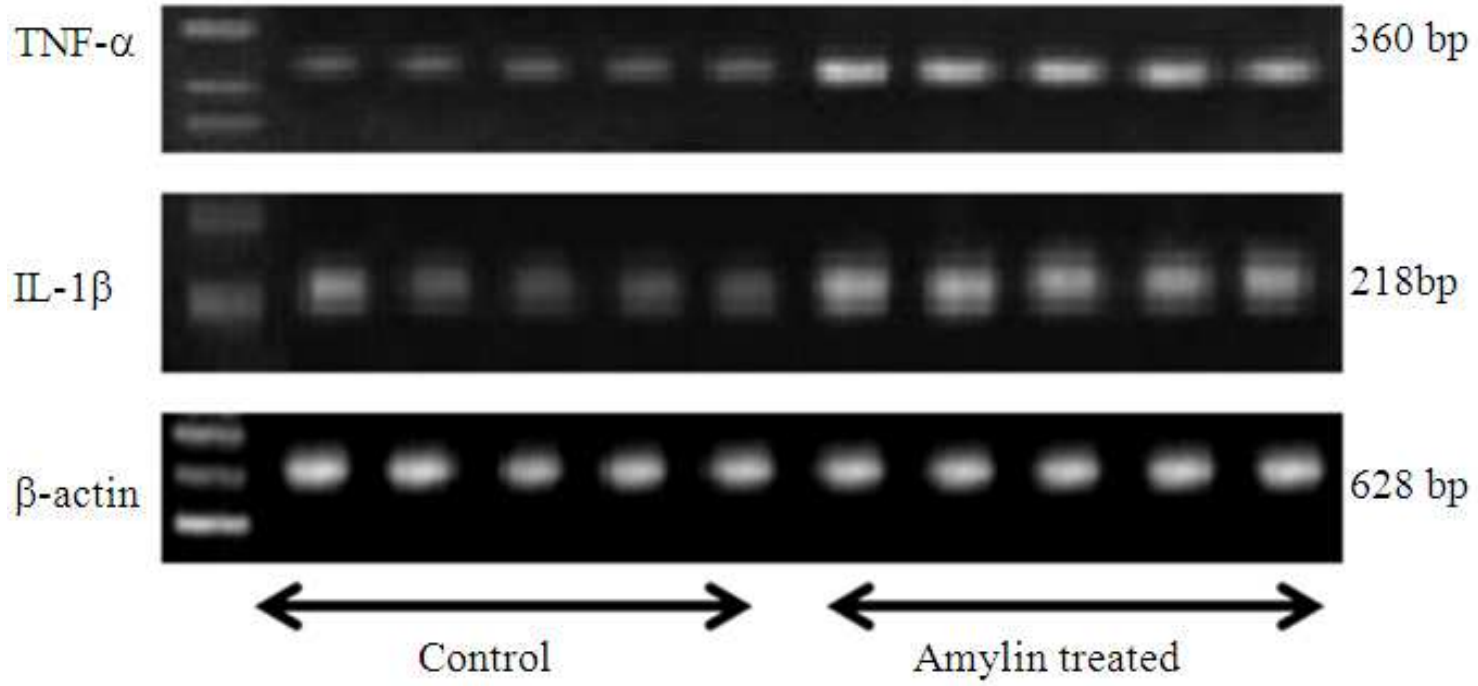

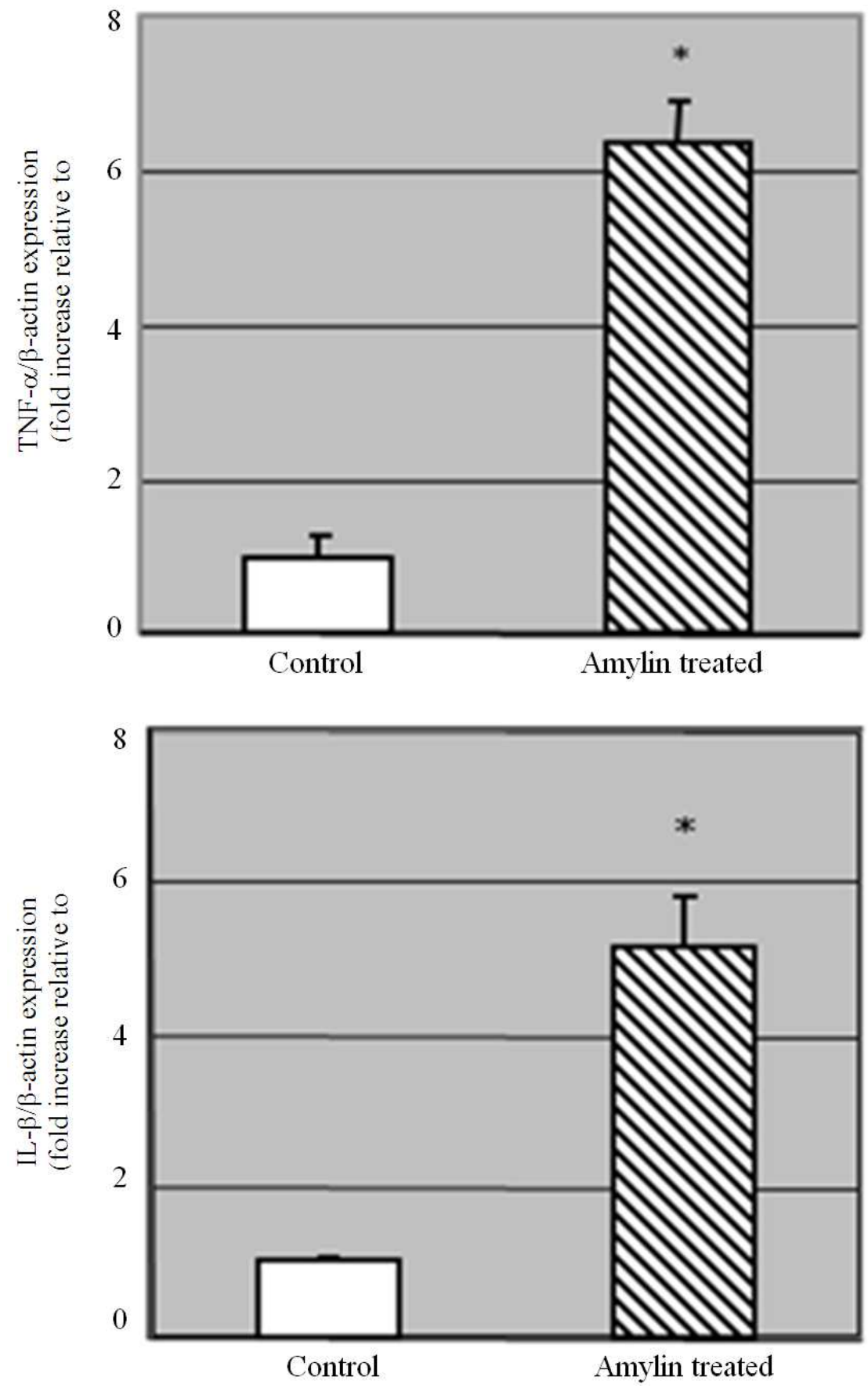

Fig. 3. RT-PCR analysis of TNF- $\alpha$, IL1- $\beta \square$ and $\beta$-actin as house keeping gene in liver of wister rats. Rats were treated intraperitonealy (ip) with either saline or amylin $\left(10 \mu \mathrm{g} \mathrm{kg}^{-1}\right)$ twice daily for 7 days. RNA was extracted and reverse transcribed $(1 \mu \mathrm{g})$ and RT-PCR analysis was carried out as seen in upper bands for TNF- $\alpha$, IL1- $\beta$ and b-actin. The densitometric analysis of expressed bands (lower columns) was normalized with that of $\beta$-actin relative to control. Values are means \pm SEM obtained from 5 different rats. ${ }^{*} p<0.05$ vs. compared to control. All samples were normalized on the basis of $\beta$ actin expression 
Figure 2 shows that amylin induced significant $(\mathrm{p}<0.05)$ decrease in cholesterol (124 \pm 5.6 versus $82.5 \pm 3.2 \mathrm{mg}$ $\left.\mathrm{dl}^{-1}\right)$, triglycerides $\left(207.5 \pm 15.5\right.$ versus $\left.65 \pm 5.4 \mathrm{mg} \mathrm{dl}^{-1}\right)$ and LDL $\left(40.75 \pm 5.06\right.$ versus $\left.56 \pm 5.7 \mathrm{mg} \mathrm{dl}^{-1}\right)$ and an increase in HDL (28.75 \pm 0.75 versus $\left.20.25 \pm 1.54 \mathrm{mg} \mathrm{dl}^{-1}\right)$ for amylin and control treated rats respectively.

\subsection{Effect of Amylin Injection on liver IL-1 $\beta$ and TNF- $\alpha$ Expression in Wistar Rats}

RNA was extracted from liver and reverse transcribed using RT-PCR analysis to examine effects of amylin on cytokines expression. As seen in Fig. 3, amylin upregulated IL-1 $\beta$ and TNF- $\alpha$ expression in liver of Wistar rats. IL-1 $\beta$ and TNF- $\alpha$ expressions were increased significantly in amylin injected rats compared to control. When their expression normalized with $\beta$-actin, the expression was 5 fold increase for TNF- $\alpha$ and 4 folds for IL-1 $\beta$.

\section{CONCLUSION}

Present findings showed that injection of amylin reduced food intake and body weight gain in a time dependent manner. Previous reports showed that amylin administration to rats or mice before meal resulted in reduction of food intake (Butler et al., 1990). Moreover, treatment of rats with amylin antagonists increases food intake and body weight that mediated through central effect of amylin (Rushing et al., 2000a; 2000b; Rushing, 2003). The amylin induced reductions in food intake and body weight may be through amylin-inhibition of gastric emptying and gastric acid secretion. It was reported that a central bolus infusion of amylin $100 \mathrm{pM}$ into the third ventricle significantly decreased $24 \mathrm{~h}$ food intake by over $30 \%$ in rats (Rushing et al., 2000a). Amylin induced weight loss in our study may be through its satiety effect because amylin was shown to cause anorexia through its effect on brain serotonin levels by increasing the transport of the precursor tryptophan into the brain (Chance et al., 1992). Serotonin reduced the size and duration of meals as well as the rate of eating. Indeed, the satiety effect of amylin was proved by enhanced weight gain of amylin-/-mice, which exhibit reducing response to the anorectic actions of exogenous cholecystokinin and bombesin (Mollet et al., 2003). The cause for hypoglycemia in this study is primary due to the inhibitory effect on food intake in addition to the inhibitory effect of amylin on glucagon (Wang et al., 1999) and secondary to the increase in leptin and insulin levels. In our study, amylin injection increased insulin levels in agreement with the facts showed that amylin infusion alone led to marked increases in plasma insulin (Ye et al., 2001) and insulin resistance states (Kahn et al., 1999). Amylin's best-known peripheral action is a potent inhibition of stomach emptying and that consistent with the hypothesis that amylin is involved in the regulation of energy balance (Young, 1997).

Importantly and analogously to insulin, amylin reduces food intake without making animals ill. Moreover, there is a sufficient evidence to include amylin with insulin and leptin as circulating adiposity signal to the brain (Roth et al., 2008). Obese individuals are at increased risk for diabetes, hypertension, renal failure and other cardiovascular diseases (Hall, 2003; Havel, 2004; Trayhurn and Beattie, 2001). Clinical and animal studies have confirmed a strong relationship between obesity and hypertension as well as diabetes (Sironi et al., 2004). Amylin treatment increased leptin secretion significantly relative to control. The amylininduced leptin induction may be through insulin induction as consistent interaction between insulin and leptin was reported in vivo and vitro (Havel, 2000). Our findings showed that amylin induced significant decrease in cholesterol, triglycerides, LDL and an increase in HDL. These findings clearly confirm that amylin has leptin like actions or at least amylin induced its effect through stimulating the secretion of lipolysis related proteins as leptin and lipase. Other studies (Trevaskis et al., 2008; 2010) reported that amylin plus leptin-mediated synergistic effect on weight loss through not only reduction in food intake but also by enhancing systemic lipid metabolism in accordance with our findings. Moreover, amylin reduced plasma triglycerides by $31 \%$, cholesterol by $10 \%$ compared with vehicle controls through increase in lipase secretion that has a potential role in lipolysis (Roth et al., 2008). It have been shown that amylin-induced secretion of IL- $\beta$ and IL- 6 in human glioma cells and obesity is associated with increase in cytokine profiles and amylin levels correlate with the degree of body adiposity (Gitter et al., 2000; Sironi et al., 2004). The brain's role in feeding is often traced to the concept of energy homeostasis, that managed by two sets of signals. One set arises from tissue stores, especially adipose tissue and referred as long-term signaling (Halford and Blundell, 2000; Blundell, 2006). The second chemical signals include leptin, insulin and certain cytokines, possibly amylin, visfatin and adiponectin (Blundell, 2006). Among such cytokines are TNF and IL-1 $\beta$ that play a role in inflammatory mediators of type 2 diabetes and obesity (Masters et al., 2010; Roth et al., 2006). The increase in IL- $1 \beta$ and TNF reported in this study may be associated 
with the increase in leptin and or insulin secretion. As, amylin increased the expression of IL-1 $\beta$ and IL-5 in macrophages and eosinophils respectively (Zhou et al., 2010) and increased IL-1 and TNF in murine microglia cells (Yates et al., 2000). IL-1 is involved in the pathogenesis of type 1 diabetes and is a risk factor for type 2 diabetes (Spranger et al., 2003). So the increase in IL-1 may be secondary to the increase in insulin and leptin reported in this study, as insulin stimulates leptin secretion and expression (Sachot et al., 2004). Moreover, several cytokines, such as IL-1 $\beta$, IFN- $\gamma$, TNF- $\alpha$, leptin, resistin, adiponectin and visfatin, diversely regulate pancreatic $\beta$ cell function (Wang et al., 2010) and that explains the increase in TNF expression in liver. Collectively the effects of amylin on cytokines secretion and expression need further in vitro studies to outline such regulation mechanism. In conclusion, this study showed that amylin has anti-obesity like actions through its modulation of leptin and insulin secretion, decrease in food intake, body weight and modulation of obesity related cytokines.

\section{ACKNOWLEDGMENT}

This study was supported in part by a Grant-in-Aid of the dean of Scientific Research (No.845-1-1431), Faculty of Applied Medical Sciences, Taif University, Saudi Arabia.

\section{REFERENCES}

Blundell, J.E., 2006. Perspective on the central control of appetite. Obesity, 4: 160S-163S. PMID: 16931499

Butler, P.C., J. Chou, W.B. Carter, Y.N. Wang and B.H. Bu et al., 1990. Effects of meal ingestion on plasma amylin concentration in NIDDM and nondiabetic humans. Diabetes, 39: 752-756. PMID: 2189768

Chance, W.T., A. Balasubramaniam, I. Thomas and J.E. Fischer, 1992. Amylin increases transport of tyrosine and tryptophan into the brain. Brain Res., 593: 2024. DOI: 10.1016/0006-8993(92)91257-F

Christopoulos, A., G. Christopoulos, M. Morfis, M. Udawela and M. Laburthe et al., 2003. Novel receptor partners and function of receptor activitymodifying proteins. J. Biol. Chem., 278: 3293-3297. PMID: 12446722

Cooper, G.J., 1994. Amylin compared with calcitonin gene-related peptide: Structure, biology, and relevance to metabolic disease. Endocr. Rev., 15: 163-201. PMID: 8026387

Gebre-Medhin, S., H. Mulder, M. Pekny, G. Westermark and J. Tornell et al., 1998. Increased insulin secretion and glucose tolerance in mice lacking islet amyloid polypeptide (amylin). Biochem. Bioph. Res. Commun., 250: 271-277. PMID: 9753619
Gitter, B.D., L.M. Cox., C.D. Carlson and P.C. May, 2000. Human amylin stimulates inflammatory cytokine secretion from human glioma cells. Neuroimmunomodulation, 7: 147-152. PMID: 10754402

Halford, J.C. and J.E. Blundell, 2000. Separate systems for serotonin and leptin in appetite control. Ann. Med., 32: 222-232. PMID: 10821329

Hall, J.E., 2003. The kidney, hypertension and obesity. Hypertension, 41: 625-633. PMID: 12623970

Hartter, E., T. Svoboda, B. Ludvik, M. Schuller and B. Lell et al., 1991. Basal and stimulated plasma levels of pancreatic amylin indicate its cosecretion with insulin in humans. Diabetologia, 34: 52-54. PMID: 2055340

Havel, J.P., 2004. Hormones: Regulation of energy balance and carbohydrate/lipid metabolism. Diabetes, 53: S143-151. PMID: 14749280

Havel, P.J., 2000. Role of adipose tissue in body-weight regulation: Mechanisms regulating leptin production and energy balance. Proc. Nutr. Soc., 59: 359-371. PMID: 10997652

Hay, D.L., G. Christopoulos, A.Christopoulos and P.M. Sexton, 2004. Amylin receptors: Molecular composition and pharmacology. Biochem. Soc. Trans., 32: 865-867. PMID: 15494035

Kahn, S.E., S. Andrikopoulos and C.B. Verchere, 1999. Islet amyloid: A long-recognized but underappreciated pathological feature of type 2 diabetes. Diabetes, 48: 241-253. PMID: 10334297

Lutz, T.A., A. Mollet, P.A. Rushing, T. Riediger and E. Scharrer, 2001. The anorectic effect of a chronic peripheral infusion of amylin is abolished in Area Postrema/Nucleus of the Solitary Tract (AP/NTS) lesioned rats. Int. J. Obes. Relat. Metab. Disord., 25: 1005-1011. PMID: 11443499

Lutz, T.A., E. Del Prete and E. Scharrer, 1994. Reduction of food intake in rats by intraperitoneal injection of low doses of amylin. Physiol. Behav., 55: 891-895. PMID: 8022910

Lutz, T.A., R. Rossi, J. Althaus, E. Del Prete and E. Scharrer, 1998. Amylin reduces food intake more potently than Calcitonin Gene-Related Peptide (CGRP) when injected into the lateral brain ventricle in rats. Peptides, 19: 1533-1540. PMID: 9864060

Martinez, A., S. Kapas, M.J. Miller, Y. Ward and F. Cuttitta, 2000. Coexpression of receptors for adrenomedullin, calcitonin gene-related peptide, and amylin in pancreatic beta-cells. Endocrinology, 141: 406-411. PMID: 10614663 
Masters, S.L., A. Dunne, S.L. Subramanian, R.L. Hull and G.M. Tannahill et al., 2010. Activation of the NLRP3 inflammasome by islet amyloid polypeptide provides a mechanism for enhanced IL-1 $\beta$ in type 2 diabetes. Nat. Immunol., 11: 897-904. PMID: 20835230

Mollet, A., S. Meier, V. Grabler, S. Gilg and E. Scharrer et al., 2003. Endogenous amylin contributes to the anorectic effects of cholecystokinin and bombesin. Peptides, 24: 91-98. PMID: 12576089

Muff, R., W. Born and J.A. Fischer, 2001. Adrenomedullin and related peptides: Receptors and accessory proteins. Peptides, 22: 1765-1772. PMID: 11754962

Mulder, H., S. Gebre-Medhin, C. Betsholtz, F. Sundler and B. Ahren, 2000. Islet amyloid polypeptide (amylin)-deficient mice develop a more severe form of alloxan-induced diabetes. Am. J. Physiol., 278: E684-E691. PMID: 10751203

Roth, J.D., B.L. Roland, R.L. Cole, J.L. Trevaskis and C. Weyer et al., 2008. Leptin responsiveness restored by amylin agonism in diet-induced obesity: Evidence from nonclinical and clinical studies. Proc. Natl. Acad. Sci. USA., 105: 7257-7262. PMID: 18458326

Roth, J.D., H. Hughes, E. Kendall, A.D. Baron and C.M. Anderson, 2006. Antiobesity effects of the beta-cell hormone amylin in diet-induced obese rats: Effects on food intake, body weight, composition, energy expenditure and gene expression. Endocrinology, 147: 5855-5864. PMID: 16935845

Rushing, P.A., 2003. Central amylin signaling and the regulation of energy homeostasis. Curr. Pharm., 9: 819-825. PMID: 12678881

Rushing, P.A., M.M. Hagan, R.J. Seeley, T.A. Lutz and D.A. D'Alessio et al., 2001. Inhibition of central amylin signaling increases food intake and body adiposity in rats. Endocrinology, 142: 5035-5035. PMID: 11606473

Rushing, P.A., M.M. Hagan, R.J. Seeley, T.A. Lutz and S.C. Woods, 2000a. Amylin: A novel action in the brain to reduce body weight. Endocrinology, 141: 850-853. PMID: 10650969

Rushing, P.A., M.M. Hagan, R.J. Seeley and S.C. Woods, 2000b. Amylin and insulin interact to reduce food intake in rats. Horm. Metab. Res., 32: 62-56. PMID: 10741687

Sachot, C., S. Poole and G.N. Luheshi, 2004. Circulating leptin mediates lipopolysaccharide-induced anorexia and fever in rats. J. Physiol., 561: 263-272. PMID: 15388782
Sironi, A.M., A. Gastaldelli, A. Mari, D. Ciociaro and V. Postano et al., 2004. Visceral fat in hypertension: Influence on insulin resistance and beta-cell function. Hypertension, 44: 127-133. PMID: 15262911

Spranger, J., A. Kroke, M. Mohlig, K. Hoffmann and M.M. Bergmann et al., 2003. Inflammatory cytokines and the risk to develop type 2 diabetes: Results of the prospective population-based European Prospective Investigation into Cancer and Nutrition (EPIC)-Potsdam Study. Diabetes, 52: 812-817. PMID: 12606524

Trayhurn, P.J. and H. Beattie, 2001. Physiological role of adipose tissue: White adipose tissue as an endocrine and secretory organ. Proc. Nutr. Soc., 60: 329-339. PMID: 11681807

Trevaskis, J.L., C. Lei, J.E. Koda, C. Weyer and D.G. Parkes et al., 2010. Interaction of leptin and amylin in the long-term maintenance of weight loss in diet-induced obese rats. Obesity, 18: 21-26. PMID: 19543217

Trevaskis, J.L., T. Coffey, R. Cole, C. Leia and C. Wittmer et al., 2008. Amylin-mediated restoration of leptin responsiveness in diet-induced obesity: Magnitude and mechanisms. Endocrinology, 149: 5679-5687. PMID: 18669592

Wang, C., Y. Guan and J. Yang, 2010. Cytokines in the Progression of Pancreatic $\beta$-Cell Dysfunction. Int. J. Endocrinol., 2010: 1-10. PMID: 21113299

Wang, F., T.E. Adrian, G.T. Westermark, X. Ding and T. Gasslander et al., 1999. Islet amyloid polypeptide tonally inhibits beta-, alpha-, and delta-cell secretion in isolated rat pancreatic islets. Am. J. Physiol., 276: E19-E24. PMID: 9886946

Yates, S.L., L.H. Burgess, J. Kocsis-Angle, J.M. Antal and M.D. Dority et al., 2000. Amyloid beta and amylin fibrils induce increases in proinflammatory cytokine and chemokine production by THP-1 cells and murine microglia. J. Neurochem., 74: 10171025. PMID: 1069393

Ye, J.M., M. Lim-Fraser, G.J. Cooney, G.J. Cooper and M.A. Iglesias et al., 2001. Evidence that amylin stimulates lipolysis in vivo: A possible mediator of induced insulin resistance. Am. J. Physiol. Endocrinol. Metab., 280: E562-E569. PMID: 11254462

Young, A., 1997. Role of amylin in nutrient intakeanimal studies. Diabet. Med., 14: S14-18. PMID: 9212324

Zhou, R., A. Tardivel, B. Thorens, I. Choi and J. Tschopp, 2010. Thioredoxin-interacting protein links oxidative stress to inflammasome activation. Nat. Immunol., 11: 136-140. PMID: 20023662 